\title{
Present and Past Deposition of Heavy Metals in Poland as Determined by Moss Monitoring
}

\author{
Pawel Kapusta*, Grażyna Szarek-Lukaszewska, Barbara Godzik \\ W. Szafer Institute of Botany, Polish Academy of Sciences, \\ Lubicz 46, 31-512 Kraków, Poland \\ Received: 15 April 2014 \\ Accepted: 8 July 2014
}

\begin{abstract}
This study investigates the air deposition of heavy metals (past and recent) in Poland using a common bioindicator - moss Pleurozium schreberi. In 2010 moss samples were collected from 320 sites evenly distributed throughout the country; 297 sites coincided with those in which the 1995 survey was carried out. In green parts of mosses, the concentrations of $\mathrm{Cd}, \mathrm{Cu}, \mathrm{Fe}, \mathrm{Pb}$, and $\mathrm{Zn}$ were determined. The 2010 data were compared with those from 1995. The moss concentration of most of the studied metals decreased significantly $(\mathrm{P}<0.05)$ between the surveyed years: from 0.45 to $0.30 \mathrm{mg} \mathrm{Cd} \cdot \mathrm{kg}^{-1}$, from 7.6 to $6.0 \mathrm{mg} \mathrm{Cu} \cdot \mathrm{kg}^{-1}$, from 362 to $344 \mathrm{mg} \mathrm{Fe} \cdot \mathrm{kg}^{-1}$, and from 18.8 to $4.9 \mathrm{mg} \mathrm{Pb} \cdot \mathrm{kg}^{-1}$, taking into account median values. This temporal trend was dependent on region (for some provinces decreases were insignificant). The concentration of $\mathrm{Zn}$ did not alter in time; median values of this variable were 42.8 and $47.5 \mathrm{mg} \cdot \mathrm{kg}^{-1}$ in 1995 and 2010, respectively. The spatial patterns of the heavy metal concentrations in mosses were similar in both surveys; southern parts of Poland, industrialized and densely populated, were contaminated more than the rest of the country.
\end{abstract}

Keywords: heavy metals, air pollution, moss monitoring, spatio-temporal pattern, Poland

\section{Introduction}

Heavy metals released into the environment due to anthropogenic activities pose a serious threat to the functioning of ecosystems and human health. This is particularly true of elements that have no known metabolic function such as cadmium, lead, and mercury - they have been identified as being highly poisonous at low concentrations [1] and, therefore, proposed by the 1998 Aarhus Protocol as primary targets of national and international monitoring programs. In Poland, direct measurements of atmospheric emissions and depositions of heavy metals are annually performed by the Voivodeship Inspectorates for Environmental Protection under State Environmental Monitoring. This instrumental monitoring is expensive and cannot be realized with high spatial resolution [2].

\footnotetext{
*e-mail: p.kapusta@botany.pl
}

Consequently, it is used more to control well-known (usually large) sources of pollution than to detect new (usually smaller) ones, and may lead to an underestimation of the overall environmental load of heavy metals.

The problem of spatial (and temporal) resolution in air pollution studies can be largely reduced using bioindicators. Bioindicators are widespread and easy-to-collect organisms that provide a quantitative measurement on the quality of the ambient environment [2]. For assessment of the atmospheric deposition of heavy metals, mosses (Bryophyta) are among the most common and longest used [3]. These plants were selected as candidates for an environmental monitoring tool for the first time by Rühling and Tyler [4] because of certain morphological, anatomical, and physiological features (e.g., forming carpet-like structures, lack of cuticle, a high surface area-to-volume ratio, lack of root nutrition) that seemed to favor the efficient capture of airborne pollutants. Environmentalists quickly adopted the 
moss monitoring method. In the 1970s and 1980s it became widely used in Europe [4, 5], which was a prerequisite for the creation of integrated monitoring within the European Heavy Metal Deposition Program (the Nordic Working Group on Monitoring and Data) and the European International Cooperative Program on Effects of Air Pollution on Natural Vegetation and Crops (ICP Vegetation Group), involving many countries. Poland joined the international monitoring programs in 1990, pledging to conduct moss surveys every five years.

This paper reports the results of the most recent (2010) Polish moss monitoring. In particular, it shows the spatial patterns and, by combining present and past (1995) data, temporal changes in the atmospheric deposition of cadmium $(\mathrm{Cd})$, copper $(\mathrm{Cu})$, iron $(\mathrm{Fe})$, lead $(\mathrm{Pb})$, and zinc $(\mathrm{Zn})$.

\section{Material and Methods}

As in past surveys, the 2010 survey was done with Pleurozium schreberi (Willd. ex Brid.) Mitt. - a terrestrial moss species that occurs commonly in Poland and is considered a sensitive indicator of air quality [6]. Mosses were collected in summer from 320 sites evenly distributed throughout the country (Fig. 1); in 297 cases the sites coincided with those in which the 1995 survey was carried out. The sites after measuring their position with a GPS receiver were attributed to the province and described in terms of the type of habitat; most of them (over $80 \%$ ) were situated in pine forests, the remaining ones in other types of forest habitats. The sites were at least $300 \mathrm{~m}$ from main roads and

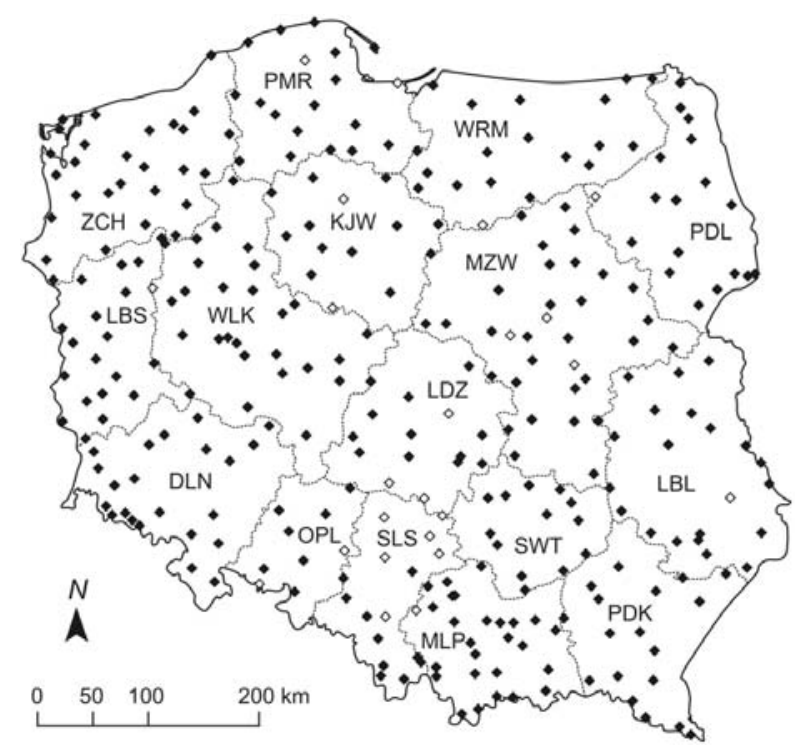

Fig. 1. Locations of 320 moss monitoring sites in 2010. Black symbols - the sites surveyed in both 1995 and 2010; white symbols - the sites surveyed only in 2010; and dashed lines - the borders of provinces. The codes for the provinces are as follows: DLN - Dolnośląskie, KJW - Kujawsko-Pomorskie, LBL Lubelskie, LBS - Lubuskie, LDZ - Łódzkie, MLP - Małopolskie, MZW - Mazowieckie, OPL - Opolskie, PDK - Podkarpackie, PDL - Podlaskie, PMR - Pomorskie, SLS - Śląskie, SWT Świętokrzyskie, WRM - Warmińsko-Mazurskie, WLK Wielkopolskie, and ZCH - Zachodniopomorskie. residential areas, and at least $100 \mathrm{~m}$ from other roads and single buildings [7]. In each site, moss samples were taken from several moss carpets growing under gaps in the tree canopy (to reduce the effect of the through-fall chemistry) and bulked into one composite sample.

Green parts of mosses, representing ca. the last three years of growth, were subjected to chemical analysis. Plant tissues were dried at $70-80^{\circ} \mathrm{C}$ and digested in a mixture of spectrally pure, concentrated acids: $\mathrm{HNO}_{3}$ and $\mathrm{HClO}_{4}$ in proportion 4:1 (vol.). The contents of $\mathrm{Cd}, \mathrm{Cu}, \mathrm{Fe}, \mathrm{Pb}$, and $\mathrm{Zn}$ were determined by atomic absorption spectrometry with atomization in air-acetylene flame or in graphite furnace (depending on element concentration) using apparatus Varian AA 280 FS Zeeman or a Varian AA280Z (with the GTA 120 graphite furnace). Moss reference materials Nos. M2 and M3 (first prepared for the 1995/6 European moss monitoring [8]) were used to control the quality of the chemical analysis.

The data obtained in 2010 were compared with those from 1995. Although moss surveys were conducted in Poland in 1990, 2000, and 2005, their results were not taken into account in this study for several reasons. In 1990 the number of sampling points was about twice as small as in 2010. Besides, the 1990 data were already used in betweenyear comparisons (1990 vs. 1995) by Grodzińska et al. [6]. Regarding more recent surveys (2000 and 2005), they were incompatible with the 2010 survey in terms of sampling scheme: in 2000, study plots were established in four select regions of the country [5]; in 2005 - in 23 national parks [9].

The data were analyzed using two-way repeated-measures ANOVA with the between-subjects factor of province $(\mathrm{N}=16)$ and the within-subjects factor of year (1995 vs. 2010). The statistical analysis involved 297 sites, i.e., the sites surveyed in both years. Prior to the analysis, outliers were removed from the data and the variables were transformed with a logarithmic or exponential function to obtain a normal or symmetrical distribution before being normalized (scaled between 0 and 1). Spatial patterns of the heavy metal deposition in 1995 and 2010 were mapped by geostatistical methods: spatial structures were modeled with spherical functions (variograms) and variables were interpolated over the study area (Poland) using ordinary kriging [10]. The statistical analysis was done with STATISTICA 9 (StatSoft Inc. Tulsa, Ok., USA) while the geostatistical one - with Surfer 8 (Golden Software Inc., Golden, Col., USA).

\section{Results}

Mean values and other descriptive statistics for concentrations of five heavy metals in mosses (calculated for all study sites) are given in Table 1. Except for $\mathrm{Zn}$, these concentrations were significantly lower in 2010 compared to 1995 (Table 2). A particularly large, and covering the whole country, between-year decrease (almost three-fold) occurred for $\mathrm{Pb}$ (Fig. 2). Similar changes in time, but less spectacular, and limited to some regions, were found for $\mathrm{Cd}$ 
Table 1. Descriptive statistics on the concentrations $\left(\mathrm{mg} \cdot \mathrm{kg}^{-1}\right)$ of heavy metals in mosses Pleurozium schreberi obtained for 1995 and 2010 .

\begin{tabular}{|c|c|c|c|c|c|c|}
\hline 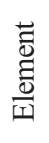 & $\stackrel{\vec{J}}{\vec{J}}$ & 艺 & 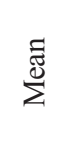 & 皱 & $\stackrel{\Xi}{\Xi} \underset{\Xi}{\Xi}$ & $\begin{array}{l}\text { 䒠 } \\
\text { 恖 } \\
\text { 穵 }\end{array}$ \\
\hline \multirow{2}{*}{$\mathrm{Cd}$} & 1995 & 297 & 0.54 & 0.45 & 0.05 & 6.3 \\
\hline & 2010 & 319 & 0.45 & 0.30 & 0.12 & 14.3 \\
\hline \multirow{2}{*}{$\mathrm{Cu}$} & 1995 & 297 & 10.7 & 7.6 & 3.5 & 650 \\
\hline & 2010 & 320 & 6.9 & 6.0 & 1.5 & 133 \\
\hline \multirow{2}{*}{$\mathrm{Fe}$} & 1995 & 293 & 450 & 362 & 87 & 5170 \\
\hline & 2010 & 320 & 405 & 344 & 110 & 2618 \\
\hline \multirow{2}{*}{$\mathrm{Pb}$} & 1995 & 297 & 17.3 & 13.8 & 4.3 & 270 \\
\hline & 2010 & 320 & 6.7 & 4.9 & 1.5 & 141 \\
\hline \multirow{2}{*}{$\mathrm{Zn}$} & 1995 & 295 & 47.5 & 42.8 & 18.6 & 208 \\
\hline & 2010 & 320 & 51.8 & 47.5 & 7.5 & 211 \\
\hline
\end{tabular}

*Number less than 297 (for 1995) or 320 (for 2010) indicates that there were missing data for a given element

and $\mathrm{Cu}$. In turn, the between-year difference in the uptake of Fe by mosses was insignificant when examined (with a post-hoc test) separately for each province. Provinces considerably differed both in all metals concentrations in mosses (see the effect of province in Table 2) and the magnitude and/or direction of temporal changes in the moss concentration of $\mathrm{Cd}, \mathrm{Fe}, \mathrm{Pb}$, and $\mathrm{Zn}$ (see the effect of interaction in Table 2).

Spatial patterns of the accumulation of heavy metals by mosses (Fig. 3) were dominated by a large-scale trend southern parts of Poland, industrialized and densely populated, were generally characterized by higher values of the variables than the rest of the country. In this respect, both surveyed years were similar. As far as the medium-scale variability is concerned, there were some differences in the temporal behavior of the moss concentration of heavy metals depending on region. For example, while the Fe and $\mathrm{Zn}$ concentrations in mosses decreased between 1995 and 2010 in the most polluted parts of the country, it increased in the areas that had been relatively clean in the past. The small-scale variability (point-to-point variability), included in variogram models (not shown here) as the nugget effect, was also an important component of the investigated spatial patterns. It was often higher than the spatially structured variance, which indicates the existence of multiple point sources of pollution affecting limited areas (not visible in the interpolated surfaces).

\section{Discussion}

This study shows that major sources of environmental pollution in Poland were and still are large industrial centers. In both surveyed years, the highest accumulation of heavy metals by mosses were recorded around metal ore mines and associated metallurgical plants (smelters), which concentrate mainly in the Legnica-Głogów region (Dolnośląskie province and Lubuskie province) and the Upper Silesia and Kraków region (Śląskie province and Małopolskie province). Mosses indicated also that in these regions, as well as in other parts of the country, the air quality has considerably improved. The findings are confirmed by direct measurements of metal emissions that have been surveyed since 1989 and published annually by the Central Statistical Office (Główny Urząd Statystyczny, GUS). According to the GUS data [11, 12], the release of metals into the atmosphere (total emissions) was reduced by about $30 \%$ for $\mathrm{Cu}, 40 \%$ for $\mathrm{Pb}$, and $50 \%$ for $\mathrm{Cd}$ and $\mathrm{Zn}$ between 1995 and 2010.

The decrease in the concentrations of heavy metals in mosses since the early 1990s to the end of the first decade of the $20^{\text {th }}$ century was observed throughout Europe. This corresponded with the observed decrease in almost in all countries of both atmospheric emissions and deposition of metals [7]. In Poland this decrease started in the late 1980s because of restructuring of heavy industry forced by political and economic transformation [13]. This included closing unprofitable plants, outsourcing unprofitable activities, and replacing outdated technology, all being generally more

Table 2. The effect of province, year, and the interaction of these factors on the concentrations of heavy metals in mosses - results of two-way repeated-measures ANOVAs.

\begin{tabular}{|c|c|c|c|c|c|c|c|c|}
\hline \multirow{2}{*}{ Element } & \multicolumn{3}{|c|}{ Between subjects } & \multicolumn{5}{c|}{ Within subjects } \\
\cline { 2 - 9 } & \multicolumn{2}{|c|}{ Province $(d f=15)$} & Error & \multicolumn{2}{|c|}{ Year $(d f=1)$} & \multicolumn{2}{c|}{ Province $\times$ Year $(d f=15)$} & Error \\
\cline { 2 - 9 } & $F$ & $P$ & $d f$ & $F$ & $P$ & $F$ & & $d f$ \\
\hline $\mathrm{Cd}$ & 37.3 & 0.000 & 272 & 150.0 & 0.000 & 3.9 & 0.000 & 272 \\
\hline $\mathrm{Cu}$ & 12.8 & 0.000 & 274 & 158.4 & 0.000 & 1.5 & 0.106 & 274 \\
\hline $\mathrm{Fe}$ & 11.5 & 0.000 & 271 & 6.3 & 0.013 & 2.7 & 0.001 & 271 \\
\hline $\mathrm{Pb}$ & 21.3 & 0.000 & 277 & 1232.6 & 0.000 & 2.9 & 0.000 & 277 \\
\hline $\mathrm{Zn}$ & 15.4 & 0.000 & 279 & 1.0 & 0.311 & 1.9 & 0.024 & 279 \\
\hline
\end{tabular}

$F$ - F statistic, $P$ - significance level, $d f$ - degrees of freedom (different values for the error term result from the different number of outliers removed from the element data) 
environmentally friendly. The changes contributed to the reduction of air pollution in terms of $\mathrm{Cd}, \mathrm{Cu}$, and $\mathrm{Pb}$, but seemed to have no effect on air-borne $\mathrm{Fe}$ and $\mathrm{Zn}$. The main source of the emissions of the latter metals (especially Fe) are steelworks. Some studies show that steel production and associated dust emission had its largest decline before 1995 $[7,13]$. This trend became much less steep in later years, which probably caused insignificant between-year differences in $\mathrm{Fe}$ and $\mathrm{Zn}$ accumulation by mosses.
A considerable improvement in air quality recorded in 2010 in the south and southwestern parts of Poland may result not only from lower emissions from the Polish territory, but also from the reduced inflow of air pollutants from abroad. Major industrial centres that might increase pollution of the environment in this area are those located in the Polish-Czech-Germany (so called 'Black Triangle'), Polish-Czech (e.g., the Ostrava industrial region) and Polish-Slovakian (e.g., the industrial area of Central Spiš)
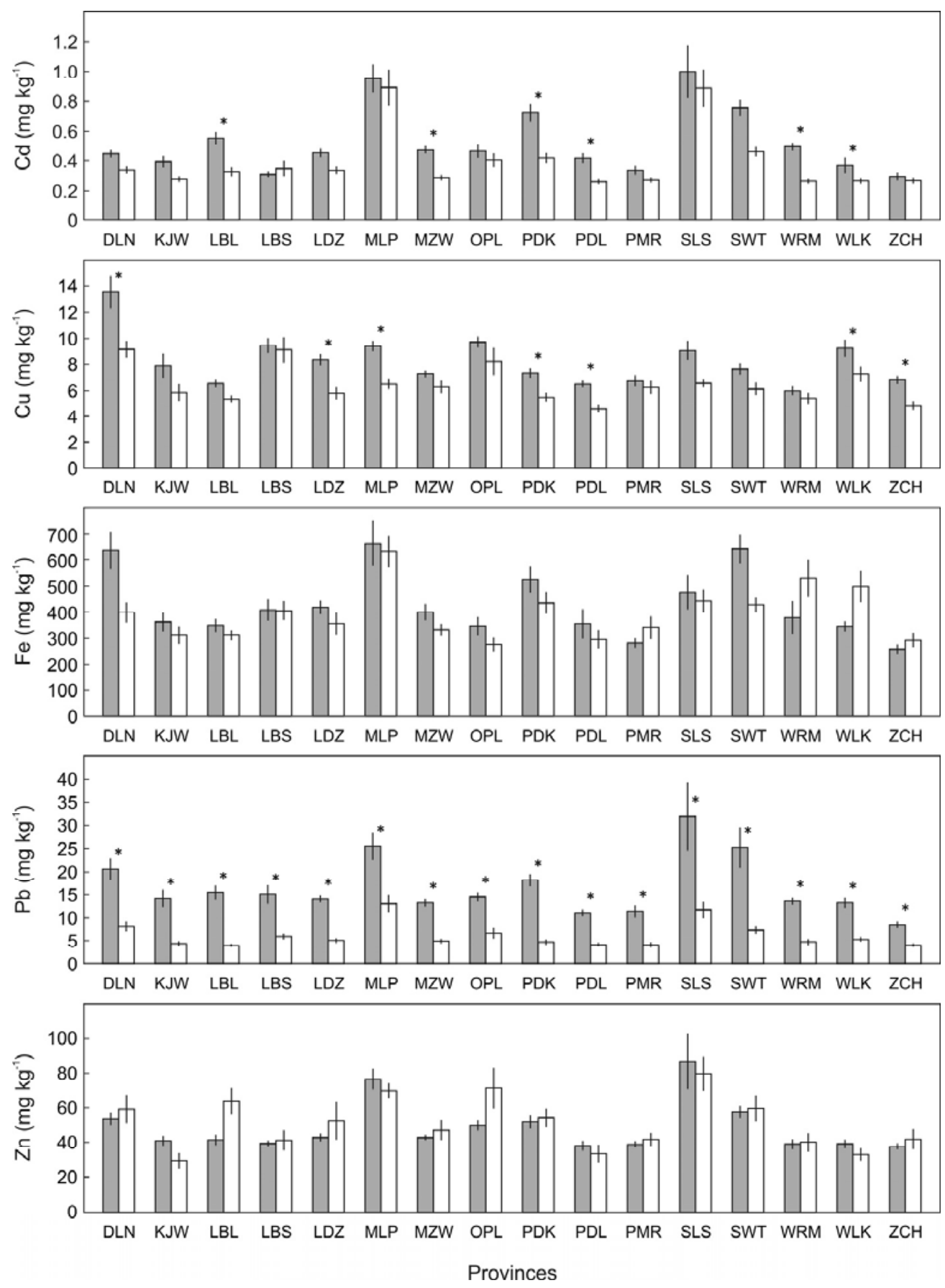

Fig. 2. Mean concentrations (with standard errors) of heavy metals in mosses in 1995 and 2010 shown by province. Asterisks indicate significant $(\mathrm{P}<0.05)$ between-year differences as revealed by post-hoc tests after ANOVAs (see Table 2 for the detailed summary of ANOVAs). The codes for the provinces are as follows: DLN - Dolnośląskie, KJW - Kujawsko-Pomorskie, LBL - Lubelskie, LBS - Lubuskie, LDZ - Łódzkie, MLP - Małopolskie, MZW - Mazowieckie, OPL - Opolskie, PDK - Podkarpackie, PDL Podlaskie, PMR - Pomorskie, SLS - Śląskie, SWT - Świętokrzyskie, WRM - Warmińsko-Mazurskie, WLK - Wielkopolskie, and $\mathrm{ZCH}$ - Zachodniopomorskie. 

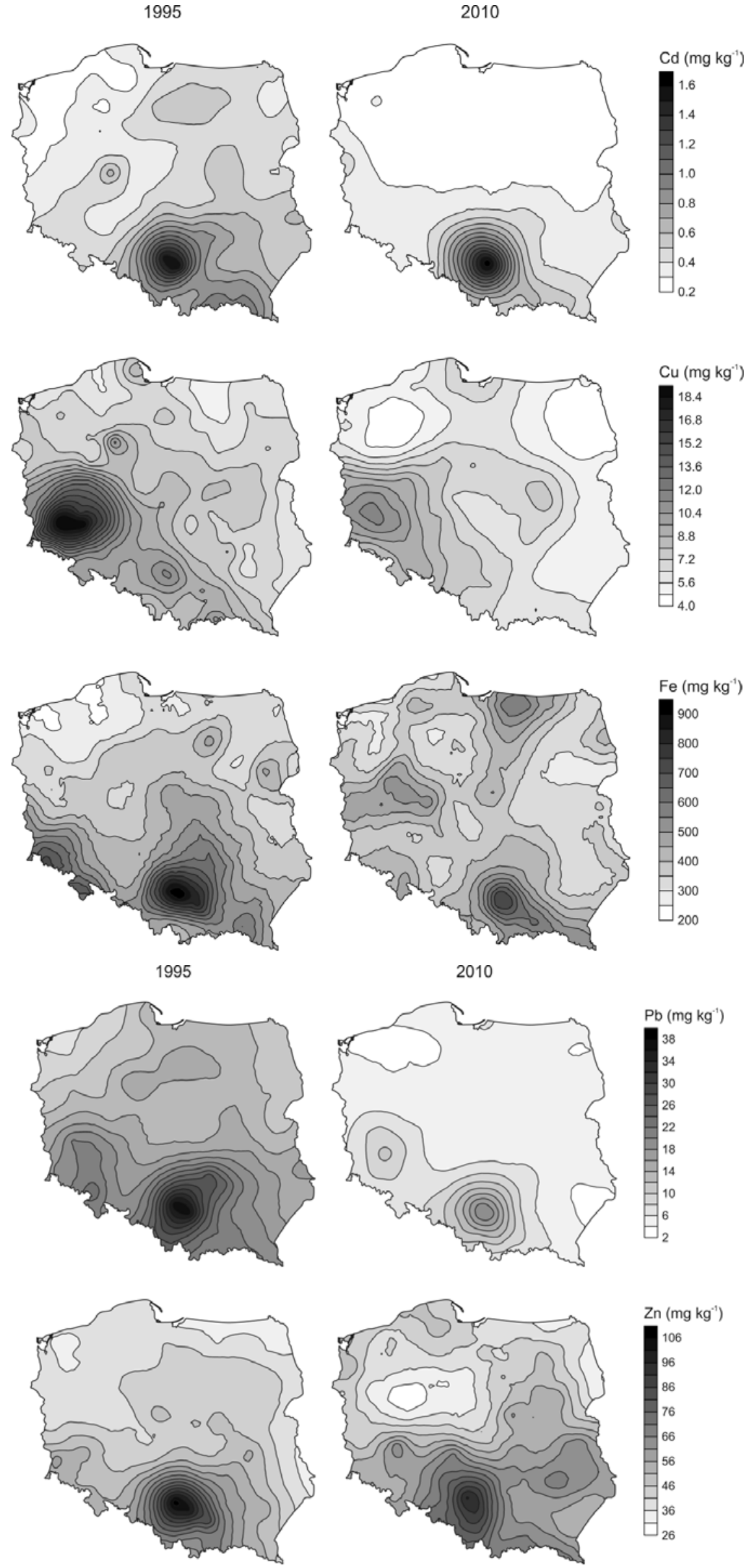

Fig. 3. Maps of the concentrations of heavy metals in 1995 and 2010. 
border zones. Taking into account the prevailing wind direction [14], they are likely to have a considerable contribution to the deposition of pollutants on the Polish side. On the contrary, there is some evidence [15] that Poland exported to the neighboring countries more metals $(\mathrm{Cd}, \mathrm{Pb}$, $\mathrm{Hg}$ ) than imported from them. Reduction of this export, for example, due to the modernization of coal power plants (especially one of the biggest - Turów Power Plant), led to lower concentrations of heavy metals in mosses in the Czech Republic [7, 16].

In Poland, even in areas remote from industrial centres and devoid of large emitters of pollutants (e.g., in the northeastern part of the country), the concentration of heavy metals in mosses is quite high. Currently, it is at least twice as high as those proposed by Zechmeister et al. [17] as a background for Europe, amounting to $0.041 \pm 0.050$ (mean \pm standard deviation) $\mathrm{mg} \mathrm{Cd} \cdot \mathrm{kg}^{-1}, 1.03 \pm 0.47 \mathrm{mg} \mathrm{Cu} \cdot \mathrm{kg}^{-1}$, $0.16 \pm 0.10 \mathrm{mg} \mathrm{Pb} \cdot \mathrm{kg}^{-1}$, and $5.0 \pm 3.4 \mathrm{mg} \mathrm{Zn} \cdot \mathrm{kg}^{-1}$. There can be many reasons for this state. One of them is certainly combustion of coal, which is still the primary heating fuel in Poland (in both households and power plants [18]) and may contain substantial amounts of heavy metals. Another source of metal pollution, particularly important in urban areas, is road transport. Undoubtedly, after the withdrawal of leaded petrol, air quality has clearly improved throughout the country (as indicated by mosses). However, many of the heavy metals (e.g., derived from abrasion of brakes and tyres as well as exhaust fumes [19]), are now released in higher amounts and affect wider areas than previously due to the increase in the number of cars (from 14 to 23 million within the 1995-2010 period [20]) and the expansion of the road network. This concerns not only common metals, such as $\mathrm{Cu}, \mathrm{Pb}$, and $\mathrm{Zn}$, but also the rarer elements (As, Sb, Se, $\mathrm{Pd}, \mathrm{Pt}, \mathrm{Rh}, \mathrm{V})$ [21] not studied here.

\section{Acknowledgements}

We are grateful to the anonymous reviewers for helpful suggestions on the manuscript. Our study was financially supported by the National Science Centre $(\mathrm{NCN})$, project No. N 304356138.

\section{References}

1. WORLD HEALTH ORGANIZATION. Health risks of heavy metals from long-range transboundary air pollution. Joint WHO/Convention Task Force on the Health Aspects of Air Pollution; WHO Regional Office for Europe: Copenhagen, 2007.

2. MARKERT B.A., BREURE A.M., ZECHMEISTER H.G. (eds.) Bioindicators and Biomonitors. Principles, concepts and applications; Elsevier: Amsterdam, Tokyo, 2003.

3. ZECHMEISTER H.G., GRODZIŃSKA K., SZAREKŁUKASZEWSKA G. Bryophytes. [In:] B.A. Markert, A.M. Breure, H.G. Zechmeister (eds.) Bioindicators and Biomonitors. Principles, concepts and applications; Elsevier: Amsterdam, Tokyo, pp. 329-375, 2003.

4. RÜHLING A., TYLER G. Ecological approach to the lead problem. Bot. Notiser, 121, 321, 1968.
5. BUSE A., NORRIS D., HARMENS H., BÜKER P., ASHENDEN T., MILLS G. Heavy metals in European mosses: 2000/2001 survey; UNECE ICP Vegetation Coordination Centre, Centre for Ecology and Hydrology: Bangor, UK, 2003.

6. GRODZIŃSKA K., SZAREK-ŁUKASZEWSKA G. Response of mosses to the heavy metal deposition in Poland - an overview. Environ. Pollut. 114, 443, 2001.

7. HARMENS H., NORRIS D., MILLS G. AND THE PARTICIPANTS OF MOSS SURVEY. Heavy metals and nitrogen in mosses: spatial patterns in 2010/2011 and long-term temporal trends in Europe; ICP Vegetation Programme Coordination Centre, Centre for Ecology and Hydrology: Bangor, UK, 2013.

8. STEINNES E., RÜHLING Å., LIPPO H., MÄKINEN A. Reference material for large-scale metal deposition surveys. Accredit. Qual. Assur. 2, 243, 1997.

9. HARMENS H., NORRIS D.A. STEINNES E., KUBIN E., PIISPANEN J., ALBER R., ALEKSIAYENAK Y., BLUM O., COSKUN M., DAM M., DE TEMMERMAN L., FERNÁNDEZ J.A., FROLOVA M., FRONTASYEVA M., GONZÁLEZ-MIQUEO L., GRODZIŃSKA K., JERAN Z., KORZEKWA S., KRMAR M., KVIETKUS K., LEBLOND S., LIIV S., MAGNÚSSON S.H., MANKOVSKÁ B., PESCH R., RÜHLING Å., SANTAMARIA J.M., SCHRÖDER W., SPIRIC Z., SUCHARA I., THÖNI L., URUMOV V., YURUKOVA L., ZECHMEISTER H.G. Mosses as biomonitors of atmospheric heavy metal deposition: Spatial patterns and temporal trends in Europe. Environ. Pollut. 158, 3144, 2010.

10. WEBSTER R., OLIVER M. Geostatistics for Environmental Scientists; Wiley: Chichester, 2001.

11. CENTRAL STATISTICAL OFFICE (GUS). Environment. Statistical information and elaboration; GUS: Warsaw, 1998.

12. CENTRAL STATISTICAL OFFICE (GUS). Environment. Statistical information and elaboration; GUS: Warsaw, 2012.

13. SZAREK-ŁUKASZEWSKA G., GRODZIŃSKA K., BRANIEWSKI S. Heavy metal concentration in moss Pleurozium schreberi in the Niepołomice Forest, Poland: changes during 20 years. Environ. Monit. Assess. 79, 231, 2002.

14. PIWKOWSKI H., MADANY A. Synoptic conditions for pollution dispersion on the Izerskie Mountains region. Przegl. Geofiz. 42, 63, 1997.

15. ILYIN I., ROZOVSKAYA O., TRAVNIKOV O., VARYGINA M., AAS W., UGGERUD H.T. Heavy metals: transboundary pollution of the environment. EMEP Status Report 2/2013; MSC-E/CCC, 2013

16. SUCHAROVÁ J., SUCHARA I., HOLÁ M., REIMANN C. Contemporary lead concentration and stable lead isotope ratio distribution in forest moss across the Czech Republic. Appl. Geochem. 40, 51, 2014.

17. ZECHMEISTER H.G., DULLINGER S., KOELLENSPERGER G., ERTL S., LETTNER C., REITER K. Do metal concentrations in moss from the Zackenberg area, Northeast Greenland, provide a baseline for monitoring? Environ. Sci. Pollut. Res. 18, 91, 2011.

18. OLECKA A., BEBKIEWICZ K., DĘBSKI B., JĘDRYSIAK P., KANAFA M., KARGULEWICZ I., RUTKOWSKI J., SĘDZIWA M., SKOŚKIEWICZ J., ZASINA D., ZIMAKOWSKA-LASKOWSKA M., ŻACZEK M. Poland's informative inventory report 2014. Submission under UN ECE Convention on Long-range Transboundary Air Pollution; National Centre for Emissions Management (KOBIZE): Warsaw, 2014. 
19. JOHANSSON C., NORMAN M., BURMAN L. Road traffic emission factors for heavy metals. Atmos. Environ. 43, 4681, 2009.

20. Polish Automotive Industry Association (PZPM). Automotive industry. Report 2012; PZPM: Warsaw, 2012 [In Polish]
21. NIEMELÄ M., PIISPANEN J., POIKOLAINEN J., PERÄMÄKI P. Preliminary study of the use of terrestrial moss (Pleurozium schreberi) for biomonitoring traffic-related $\mathrm{Pt}$ and $\mathrm{Rh}$ deposition. Arch. Environ. Contam. Toxicol. 52, 347, 2007. 
